Annals of Warsaw University of Life Sciences - SGGW

Land Reclamation No 47 (2), 2015: 163-171

(Ann. Warsaw Univ. Life Sci. - SGGW, Land Reclam. 47 (2), 2015)

\title{
Geotechnical investigation and static analysis of deep excavation walls - a case study of metro station construction in Warsaw
}

\author{
MONIKA MITEW-CZAJEWSKA \\ Institute of Roads and Bridges, Warsaw University of Technology
}

\begin{abstract}
Geotechnical investigation and static analysis of deep excavation walls - a case study of metro station construction in Warsaw. The paper presents detailed analysis of the case - a construction of deep excavation of metro station in Warsaw. Basing on this example, the great impact of the accuracy of the geotechnical investigation on the static analysis of diaphragm walls is discussed. Geotechnical studies for the construction of the central section of the second metro line were carried out in stages. Basic geotechnical soil investigation took place in the first stage of investment process, e.g. building permit and tender design stages in 2003-2004, 2007 and 2010. In subsequent years, complementary soil investigations have been performed by the contractor, and the results occurred to differ significantly. In the first part of the paper detailed description of the case is introduced. The geological conditions in the area of the station and the interpretation of the results of the three successive stages of geotechnical investigation are presented. As a result, two locations were selected with a great diversity of the soil profile depending on the stage of investigation. For each location, detailed, multiple static analysis of diaphragm walls were performed, taking into account changes in the soil profile. In the paper, one selected location is described in detail. The discussion of calculation results for this location in relation to the changing geotechnical data is presented and final conclusions are provided.
\end{abstract}

Key words: soil investigation, diaphragm wall, numerical analysis, deep excavation

\section{INTRODUCTION}

In Warsaw, nowadays, a great scope of underground works are in progress. The central part of the $2^{\text {nd }}$ metro line has just been completed and the tender for its extension in east and west direction was announced. The case, which will be further discussed, is a $24.70 \mathrm{~m}$ deep excavation for the construction of $\mathrm{C} 11$ "Świętokrzyska" metro station, one of the deepest stations within the central part of the $2^{\text {nd }}$ metro line (Fig. 1), executed in a very complex geotechnical conditions (various soft Quaternary soils and high water pressure) (Mitew-Czajewska 2014a).

Cut and cover method was used for the construction of the station; the stability of 30-33 m deep diaphragm walls during excavation was ensured by three levels of underground slabs. In the first stage of investment process, i.e. building permit design stage, the primary soil investigation was performed. Basing on the results of this investigation calculations of supporting system and the design of diaphragm walls were made. In the subsequent investment stages - tender design and technical design stages - 


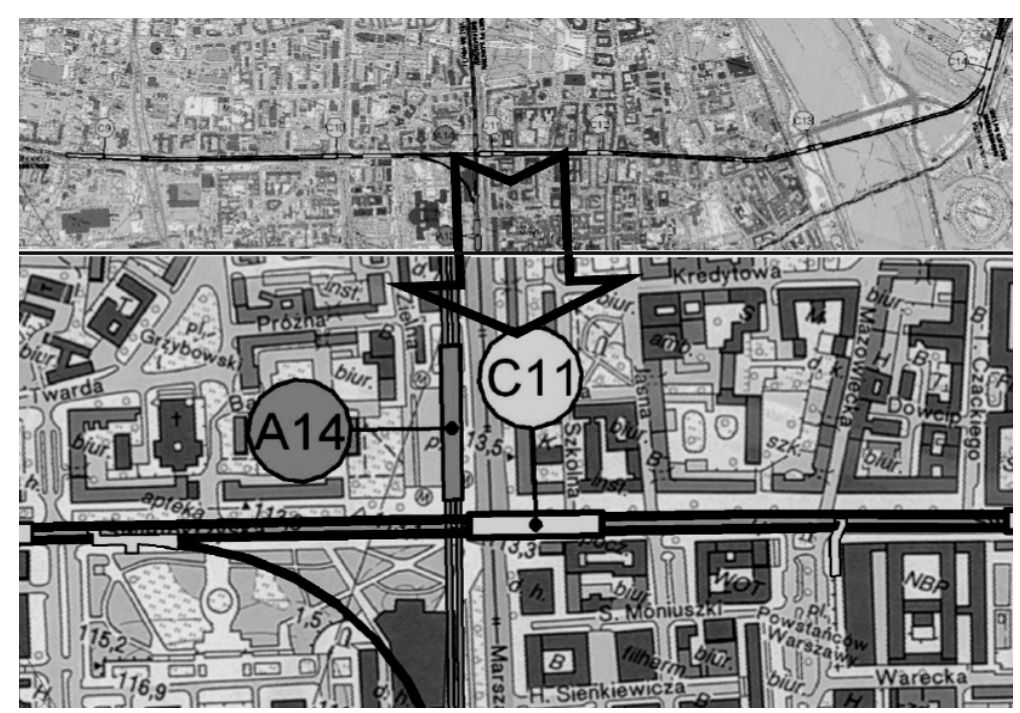

FIGURE 1. Location of C11 the "Świętokrzyska" Station; central part of the $2^{\text {nd }}$ metro line in Warsaw

complementary soil investigations were performed and the results were taken into account in the final diaphragm walls analysis, design and dimensioning. Significant differences were observed in the results of numerical analysis (displacements and internal forces) made at each investment stage.

In the paper, numerical analysis of the case with variation of soil profiles is presented in details and the discussion of the results in relation to the changing geotechnical data is performed.

\section{DESCRIPTION OF THE CASE}

\section{Geometry and construction stages}

The approximate length of $\mathrm{C} 11$ the "Świętokrzyska" Station is $137 \mathrm{~m}$ and its width $-23.6 \mathrm{~m}$. Maximum excavation depth was $24.70 \mathrm{~m}$. The typical cross-section of a station is shown in Figure 2.
The Station was built using cut and cover and top down method (ILF Consulting Engineers Polska Sp. z o.o. 2011). The following construction stages were applied after the construction of peripheral diaphragm walls:

- Stage 1 - excavation to the level of $32.30 \mathrm{~m}$ above " 0 " level of Vistula river (i.e. $3.2 \mathrm{~m}$ below ground surface);

- Stage 2 - construction of the roof slab of the upper station (top surface at $33.50 \mathrm{~m}$ above " 0 " level of Vistula river);

- Stage 3 - excavation to the level of $27.60 \mathrm{~m}$ above " 0 " level of Vistula river (i.e. $7.9 \mathrm{~m}$ below ground surface);

- Stage 4 - construction of the first/ /top intermediate slab (top surface at $28.20 \mathrm{~m}$ above " 0 " level of Vistula river); 


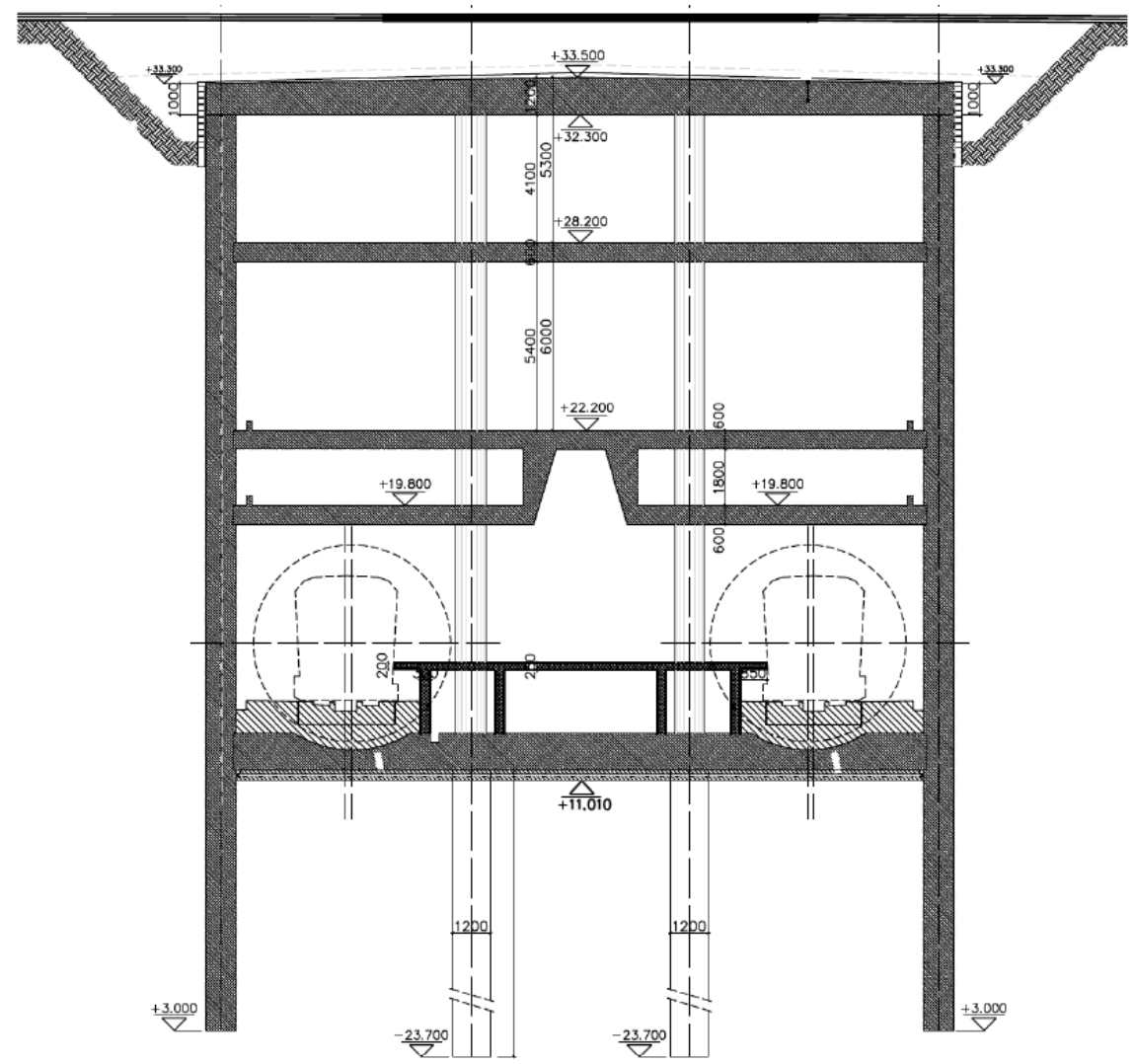

FIGURE 2. Typical cross-section of C11 the "Świętokrzyska" Station

- Stage 5 - excavation to the level of $19.20 \mathrm{~m}$ above " 0 " level of Vistula river (i.e. $16.3 \mathrm{~m}$ below ground surface);

- Stage 6 - construction of the third/ /bottom intermediate slab (top surface at $19.80 \mathrm{~m}$ above " 0 " level of Vistula river);

- Stage 7 - excavation to the level $10.80 \mathrm{~m}$ above " 0 " level of Vistula river (i.e. $24.70 \mathrm{~m}$ below ground surface);

- Stage 8 - construction of the foundation slab;

\section{Geotechnical conditions}

In central Poland, in the region of Warsaw there are very complex geological conditions. In general the subsoil is composed of Tertiary deposits topped with a complex of Quaternary formations from the Pleistocene and Holocene periods (Mitew-Czajewska 2014b, Siemińska-Lewandowska and Mitew-Czajewska 2014). The top surface of Tertiary, Pliocene layer is very uneven and irregular in the effect of three glaciations, which occurred after this period. 
This irregularity may be observed at the geotechnical cross-section drawn along a station (Fig. 3). Soil conditions at the construction site of C11 Station are as follows:

- directly under the surface, 3-5 m thick anthropogenic soils (so-called artificial fills, AF) occur;

- below the layer of fills, from 0 up to $34 \mathrm{~m}$ thick glacial formations occur mainly in form of medium to coarse sands and/or locally - clays and sandy clays;

- under the moraine layer Tertiary Pliocene clays are found, which occur as clays, silty clays or stiff silty clays. This layer is divided into two layers (I Plc and I Pld) taking into account the change in its parameters with depth.

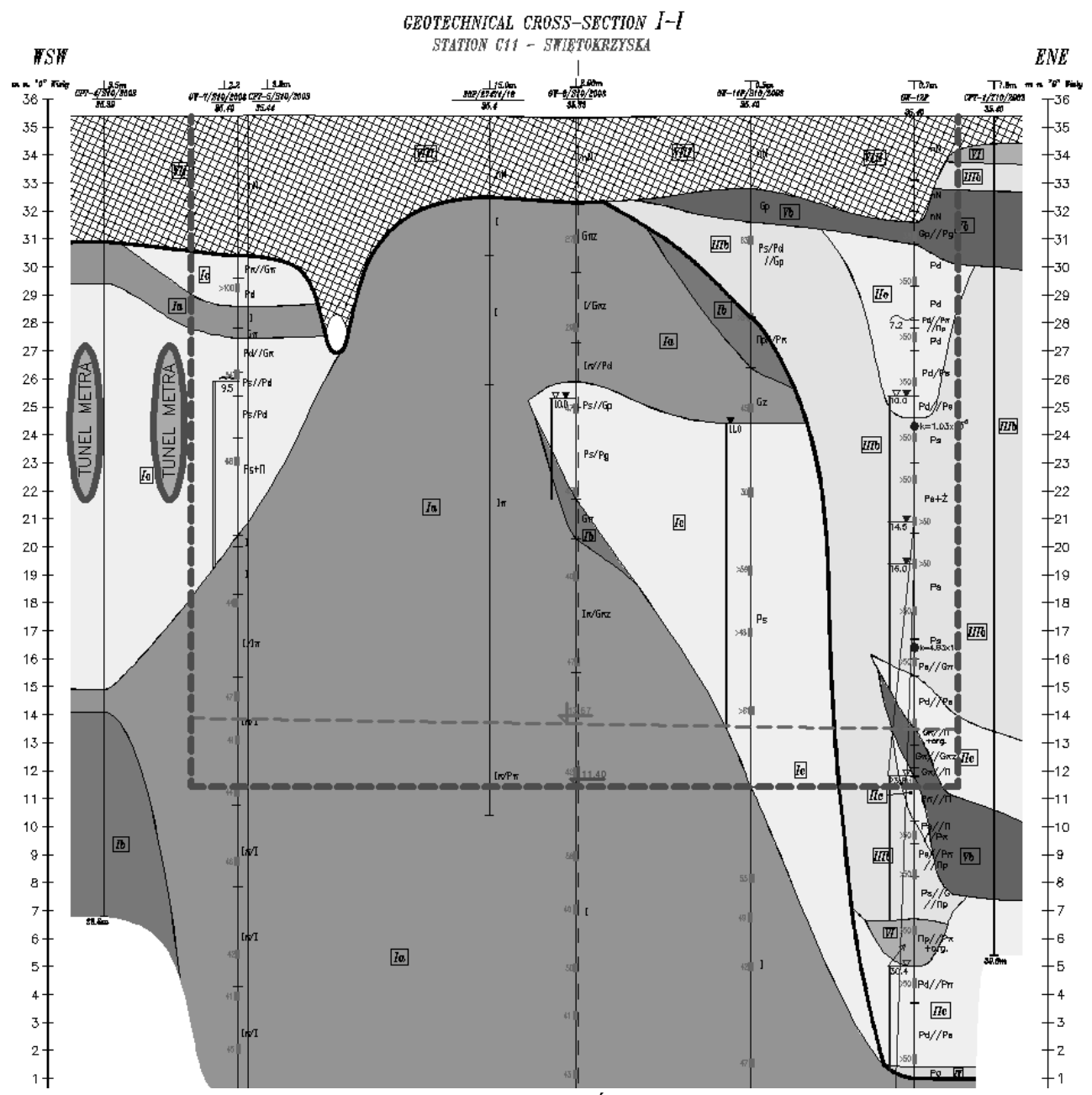

FIGURE 3. Geotechnical cross-section along C11 the "Świętokrzyska" Station 
The main groundwater level is located at $25.50 \mathrm{~m}$ above the "0" level of Vistula river (approximately $10 \mathrm{~m}$ below the ground surface).

Basic geotechnical soil parameters of all soil layers specified above are compiled in Table 1.

TABLE 1. Basic geotechnical parameters

\begin{tabular}{|l|c|c|c|}
\hline \multirow{2}{*}{ Soil layer } & $\gamma$ & $\varphi$ & $c$ \\
\cline { 2 - 4 } & $\mathrm{kN} / \mathrm{m}^{3}$ & $\circ$ & $\mathrm{kPa}$ \\
\hline $\mathrm{AF}$ & 18 & 25 & 0 \\
\hline Sand & 20 & 36 & 0 \\
\hline Clay & 20.5 & 31 & 3 \\
\hline I Pld & 21 & 18 & 15 \\
\hline
\end{tabular}

During the investment process there were several soil investigation campaigns performed. The first geotechnical investigation was performed at early investment stages, before the tender design stage 2003-2004 and 2007. There was a geotechnical report issued at that stage (Geoteko 2007). During the construction a complementary investigation was performed and the final geotechnical report was issued (Geoteko 2010). In subsequent years, complementary soil investigations have been performed by the contractor, and the results occurred to differ significantly. Two locations were selected with the greatest diversity of the soil profile depending on the stage of investigation BH-1 and BH-14. The interpretation of the results of the three successive stages of geotechnical investigation for selected locations is presented at Figure 4.

\section{NUMERICAL ANALYSIS}

\section{Basic assumptions}

Calculations were made using dependent pressures method-GEO5 Sheeting check software, which was also applied for the design of diaphragm walls at the building permit design stage. The modulus of subsoil reaction $\left(K_{h}\right)$ was calculated according to the theory of Chadeisson (Chadeisson 1961). Both selected locations were modeled (BH-1 and BH-14), concerning three soil profiles in each case. As the results of analysis did not differ significantly (BH-1 versus $\mathrm{BH}-14)$, only one location (BH-1) is presented in detail.

The following basic assumptions were adopted:

- final excavation depth $-24.7 \mathrm{~m}$;

- diaphragm wall height $-30.5 \mathrm{~m}$;

- diaphragm wall thickness $-1.2 \mathrm{~m}$;

- 3 slabs supporting the diaphragm wall; thickness of slabs (from top to bottom respectively): 1.2, 0.6, $0.6 \mathrm{~m}$;

- foundation slab thickness - $1.2 \mathrm{~m}$;

- construction stages as specified in the Description of the case section above.

The geometry of the model and geotechnical conditions considered in the analysis are presented in Figure 5.

\section{Results of analysis}

The results of all calculation series (varying soil profiles), i.e. maximum values of horizontal displacements and bending moments, are compiled in Table 2 and shown in Figures 6 and 7, respectively. 

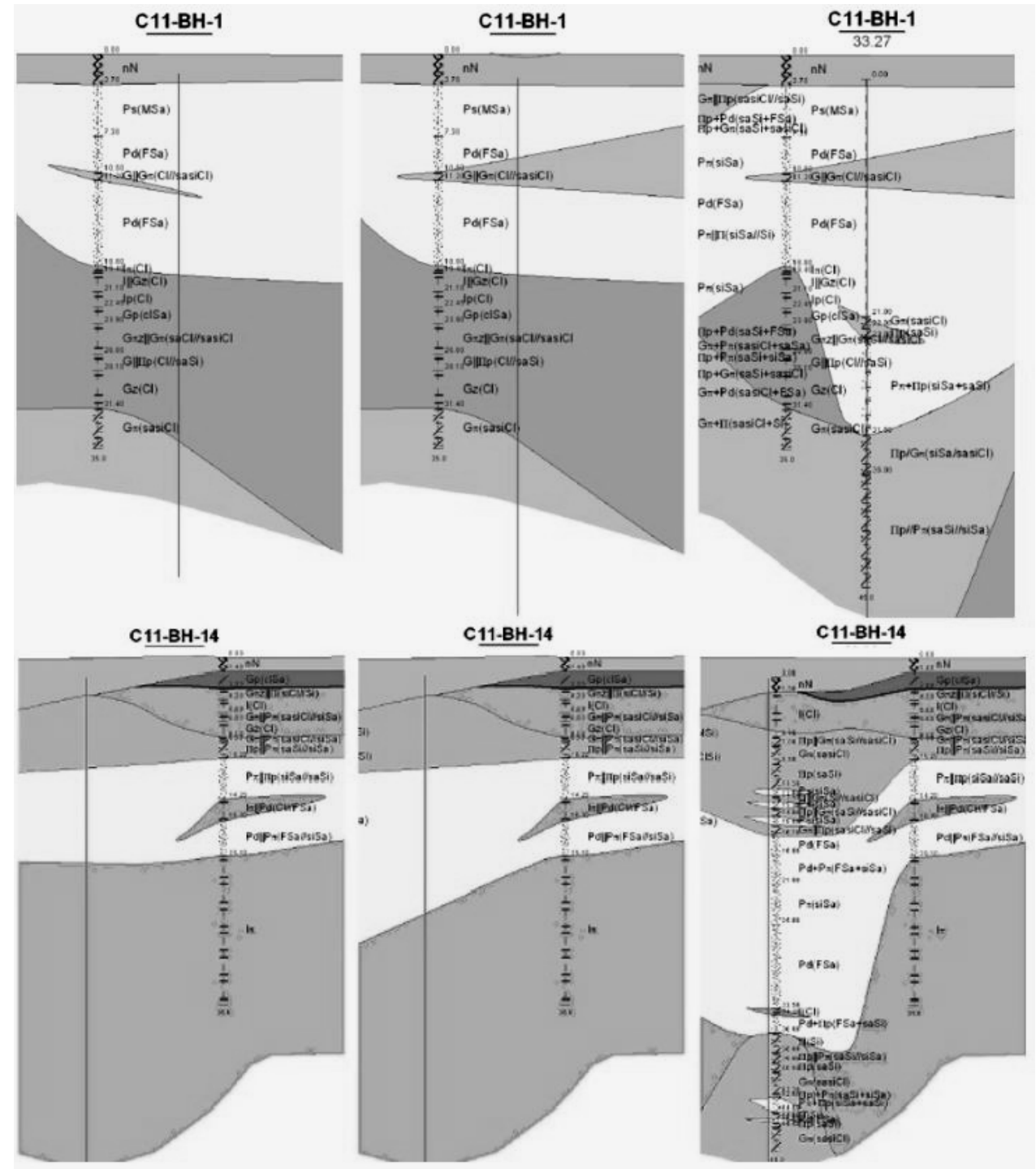

FIGURE 4. Geotechnical profiles drawn at different stages of geotechnical investigation, boreholes BH-1 and BH-14

Calculation series based on soil profiles 1 and 2, evaluated at early investment stages showed huge displacements of the bottom of the diaphragm wall (Fig. 6) as well as unrealistic values of bending moments up to $24,000 \mathrm{kNm} / \mathrm{m}$ (Fig. 7).
Which means that the wall is unstable, not fixed at the bottom, and should be significantly extended (Barański 2014). In these calculation series (profiles 1 and 2) Tertiary, Pliocene clays layer is dominating in the soil profile. Whereas, 


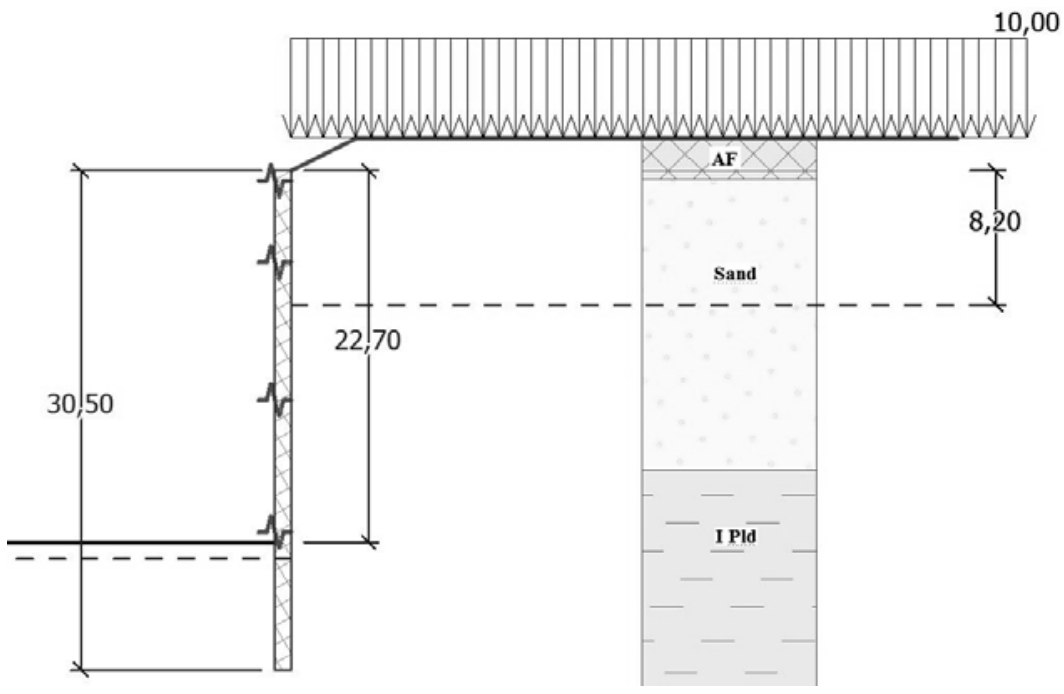

FIGURE 5. Numerical model - location BH-1

TABLE 2. The results of numerical analysis

\begin{tabular}{|l|c|c|c|c|c|c|}
\hline \multirow{2}{*}{ Item } & \multicolumn{2}{|c|}{ Profile 1 } & \multicolumn{2}{c|}{ Profile 2 } & \multicolumn{2}{c|}{ Profile 3 } \\
\cline { 2 - 7 } & $u_{\max }$ & $M_{\max } / M_{\min }$ & $u_{\max }$ & $M_{\max } / M_{\min }$ & $u_{\max }$ & $M_{\text {max }} / M_{\min }$ \\
\cline { 2 - 7 } & $\mathrm{mm}$ & $\mathrm{kNm} / \mathrm{m}$ & $\mathrm{mm}$ & $\mathrm{kNm} / \mathrm{m}$ & $\mathrm{mm}$ & $\mathrm{kNm} / \mathrm{m}$ \\
\hline $\mathrm{BH}-1$ & 546.7 & $3115 / 24,120$ & 548.9 & $3188 / 24,179$ & 16.5 & $2618 / 2293$ \\
\hline
\end{tabular}
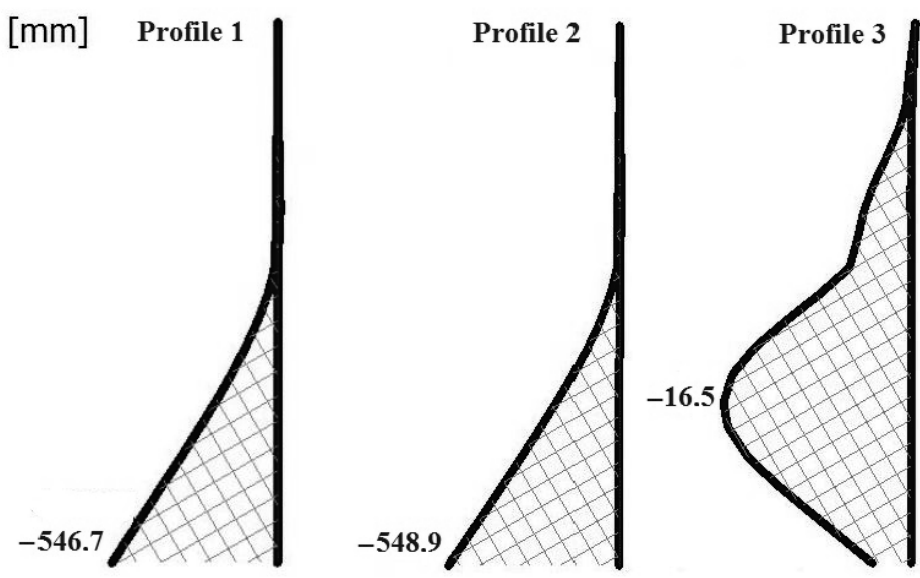

FIGURE 6. Results of numerical analysis - displacements 

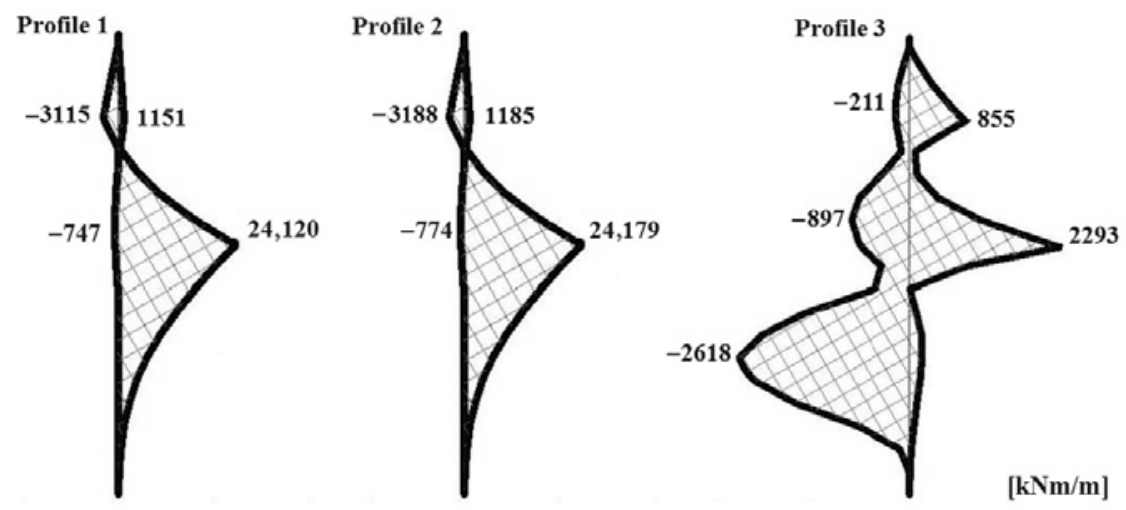

FIGURE 7. Results of numerical analysis - bending moments

in the final soil profile, evaluated basing on several complementary soil investigation reports, it turned out that the top level of Pliocene clays is suddenly dropping down (Figs 3 and 4). The analysis of the third soil profile proved to give realistic results - maximum horizontal displacement of the wall reached 16.5 $\mathrm{mm}$ and maximum bending moment $2618 \mathrm{kNm} / \mathrm{m}$.

\section{CONCLUSIONS}

In the paper, numerical analysis of the deep excavation wall with variation of soil profiles basing on several investigation reports, are presented in detail. The analysis proved that there is a significant impact of the variation of soil profile, especially when changing the extent of Tertiary, Pliocene clays layer, on the resulting values of the theoretical displacements and bending moments in the diaphragm wall. It should be underlined that, the top surface of Tertiary, Pliocene layer is very uneven and irregular in
Warsaw, which often causes problems in proper soil profiles evaluation.

The results of analysis of two soil profiles drawn basing on preliminary soil investigation data showed extensive displacement of the bottom of the wall (insufficient length of the wall) and unrealistic values of internal forces. Whereas, the analysis of the third profile (final profile), created after complementary geotechnical investigation, proved to give realistic results in terms of both lateral wall displacements and internal forces.

That allows the author to emphasize the importance of detailed soil investigation for the design of underground structures, such as deep excavations.

\section{REFERENCES}

BARAŃSKI K. 2014: Analiza statyczno-wytrzymałościowa wybranych elementów konstrukcyjnych stacji metra Świętokrzyska. [The analysis of chosen structural elements of Świętokrzyska metro station in Warsaw]. Warsaw University of Technology. Master thesis. 
CHADEISSON R. 1961: Parois continues moulées dans le sols. Proceedings of the 5th European Conerence on Soil Mechanics and Foundation Engineering, Vol. 2: 563-568. Paris: Dunod.

Geoteko Ltd. 2007. Geological-engineering and hydrological documentation for the II subway line in Warsaw.

Geoteko Ltd. 2010. Geotechnical documentation for the II subway line from "Rondo Daszyńskiego" station to "Dworzec Wileński" station in Warsaw.

ILF Consulting Engineers Polska Sp. z o.o. 2011. C11 "Świętokrzyska" station geotechnical design. Report and calculations.

MITEW-CZAJEWSKA M. 2014a: Numerical analysis of a $36 \mathrm{~m}$ deep diaphragm wall - parametric study. Proceedings of the 8th International Symposium on Geotechnical Aspects of Underground Construction in Soft Ground (ISSMGE TC204). Seoul, Korea. CRC Press, Balkema, 257-262.

MITEW-CZAJEWSKA M. 2014b: Niepewność warunków geotechnicznych w procesie budowlanym - na przykładzie budowy tunelu metra w Warszawie. [Uncertainty of geotechnical conditions in the construction process - a case study of metro tunnel construction.] Inżynieria i Budownictwo 6, 303-307.

SIEMIŃSKA-LEWANDOWSKA A., MITEW-CZAJEWSKA M. 2014: Uncertainty of geotechnical conditions - a case study of metro tunnel construction underneath the existing road tunnel. Proceedings of the World Tunnel Congress 2014 - Tunnels for a better Life. Foz do Iguaçu, Brazil.

Streszczenie: Rozpoznanie geotechniczne a analiza statyczna ścian głębokiego wykopu na przyktadzie budowy stacji metra $w$ Warszawie. W artykule przedstawiono szczegółową analizę przypadku - głębokiego wykopu stacji metra w Warszawie.
Omówiono przykład wpływu dokładności rozpoznania geotechnicznego na wyniki analizy statycznej ścian szczelinowych stanowiących obudowę wykopu. Badania geotechniczne na potrzeby budowy centralnego odcinka II linii metra były wykonywane etapowo. Podstawowe rozpoznanie geotechniczne miało miejsce na etapie projektu budowlanego i tworzenia dokumentacji przetargowej w latach 2003-2004, 2007 i 2010. W kolejnych latach badania były uzupełniane przez wykonawce inwestycji. Wyniki kolejnych etapów rozpoznania różniły się znacząco. W pierwszej części zawarto szczegółowy opis analizowanego obiektu. Przedstawiono budowę geologiczną w rejonie stacji oraz pokazano interpretację wyników trzech kolejnych etapów rozpoznania geotechnicznego. Po przeanalizowaniu przekrojów geotechnicznych wydzielonych wzdłuż ścian zewnętrznych stacji wybrano dwa punkty badawcze o bardzo zróżnicowanym profilu w zależności od etapu rozpoznania. Dla każdego z wytypowanych w ten sposób punktów wykonano wariantowe analizy statyczne ścian szczelinowych z uwzględnieniem zmian profilu gruntowego. W referacie omówiono szczegółowo jeden wybrany przypadek charakterystyczny, przedstawiono wyniki obliczeń oraz przeprowadzono ich dyskusję w odniesieniu do zmienności warunków geotechnicznych.

Stowa kluczowe: rozpoznanie geotechniczne, ściany szczelinowe, analiza numeryczna, głębokie wykopy

\section{Author's address:}

Monika Mitew-Czajewska Instytut Dróg i Mostów Wydział Inżynierii Lądowej Politechnika Warszawska al. Armii Ludowej 6, 00-637 Warszawa Poland 